\title{
Intra-abdominal pressure: an integrative review
}

\author{
Pressão intra-abdominal: revisão integrativa
}

\author{
Rafaela Milanesi ${ }^{1}$, Rita Catalina Aquino Caregnato ${ }^{2}$
}

\begin{abstract}
There is a growing request for measuring intra-abdominal pressure in critically ill patients with acute abdominal pain to be clarified. Summarizing the research results on measurement of vesical intraabdominal pressure and analyzing the level of evidence were the purposes of this integrative literature review, carried out based on the databases LILACS, MEDLINE and PubMed, from 2005 to July 2012. Twenty articles were identified, in that, 12 literature reviews, 4 descriptive and exploratory studies, 2 expert opinions, one prospective cohort study and one was an experience report. The vesical intraabdominal pressure measurement was considered gold standard. There are variations in the technique however, but some common points were identified: complete supine position, in absence of abdominal contracture, in the end of expiration and expressed in $\mathrm{mmHg}$. Most research results indicate keeping the transducer zeroed at the level of the mid-axillary line at the iliac crest level, and instill $25 \mathrm{~mL}$ of sterile saline. Strong evidence must be developed.
\end{abstract}

Keywords: Intra-abdominal hypertension; Monitoring, physiologic; Nursing care; Intensive care

\section{RESUMO}

Em pacientes críticos com quadros abdominais agudos a esclarecer é crescente a solicitação da aferição da pressão intra-abdominal. Sintetizar resultados de pesquisas sobre a mensuração da pressão intra-abdominal pela via vesical e analisar o nível de evidência foram os objetivos desta revisão integrativa da literatura, realizada nas bases LILACS, MEDLINE e PubMed, no período de 2005 a julho de 2012. Identificaram-se 20 artigos, sendo 12 revisões de literatura, 4 estudos exploratório-descritivos, 2 opiniões de especialistas, 1 estudo de coorte prospectivo e 1 relato de experiência. 0 método vesical para mensuração da pressão intra-abdominal foi considerado padrão-ouro. Existem variações na técnica, entretanto pontos em comum foram identificados: posição supina completa, na ausência de contratura abdominal, ao final da expiração e expressa em mmHg. A maioria indica posicionar o ponto zero do transdutor na linha axilar média, ao nível da crista ilíaca e instilar 25ml de solução salina estéril. Evidências fortes precisam ser desenvolvidas.

Descritores: Hipertensão intra-abdominal; Monitorização fisiológica; Cuidados de enfermagem; Terapia intensiva

\section{INTRODUCTION}

The incidence of complications arising from intraabdominal pressure (IAP) variation ${ }^{(1-5)}$ in critically ill patients suffering from acute abdomen conditions with unconfirmed diagnosis is high and justifies increasing IAP measurement requests. ${ }^{(1)}$

Intra-abdominal pressure is defined as the steady-state pressure concealed within the abdominal cavity and resulting from the interaction between the abdominal wall and viscera; IAP oscillates according to respiratory phase and abdominal wall resistance. ${ }^{(1-7)}$ Intra-abdominal pressure levels up to $5 \mathrm{mmHg}$ are considered physiological in adults; however, in patients suffering from conditions devoid of pathophysiological significance, such as obesity, IAP may range from 10 to $15 \mathrm{mmHg}$, while IAP values between 5 and $7 \mathrm{mmHg}$ are expected in critically ill patients. ${ }^{(1-14)}$

Intra-abdominal hypertension (IAH) is defined by IAP elevation above $12 \mathrm{mmHg}$ in three consecutive measurements taken at 4-to-6-hour intervals. Intraabdominal pressure may gradually progress to abdominal compartmental syndrome (ACS), with sustained IAP above $20 \mathrm{mmHg}$ and associated organ dysfunction or failure..$^{(1,4-20)}$

Abdominal compliance is limited; therefore, high, nonphysiological pressure levels interfere with tissue perfusion,

\footnotetext{
Hospital Nossa Senhora da Conceição, Porto Alegre, RS, Brazil.

2 Universidade Luterana do Brasil, Canoas, RS, Brazil.

Corresponding author: Rafaela Milanesi - Avenida Francisco Trein, 596 - Cristo Redentor - Zip code: 91350-200 - Porto Alegre, RS, Brazil - Phone: (55 51) 3357-2000 - E-mail: mrafaela@ghc.com.br Received on: Feb 17, 2014 - Accepted on: June 30, 2015
}

DOI: 10.1590/S1679-45082016RW3088 
potentially leading to severe ischemic or circulatory changes. Correlations between organ dysfunction and increased IAP have been demonstrated in patients suffering from abdominal lesions or conditions, with resulting deterioration of patient's general condition. . $^{(1-4,8,9,11-13,18,19)}$

Intra-abdominal pressure measurement system deployment and use are procedures performed by the nursing team; a theoretical background is therefore required if nurses are to properly execute the procedure, which in turn allows early recognition of the problem and ensures medical assistance with lower complication indices. ${ }^{(6)}$ Given IAP measurement reliability is a key factor in the therapeutic decision making process, trained professionals are required for safe application of the technique. ${ }^{(21)}$

However, procedural mismatches in IAP monitoring are evident ${ }^{(21,22)}$ and the correct measurement method remains to be determined, along with proper interpretation of results and establishment of time intervals between measurements. ${ }^{(1,4,22)}$ Scientific, evidence-based analysis is thus required to clarify existing uncertainties and offer quality care to patients. This study was aimed to summarize research findings concerning intravesical IAP measurement in adult patients and analyzing the respective levels of evidence. It is expected that the data presented will contribute to understand IAP and help support the clinical decision making process.

\section{METHODS}

This integrative review comprised six phases: problem delineation, literature search, data collection, critical analysis of selected studies, result presentation and discussion. In the first phase, a core question was formulated: What recent publications are there on intravesical IAP measurement in adults?

In the second phase, databases, literature search strategies, as well as inclusion and exclusion criteria were defined; selected databases were PubMed; MEDLINE and LILACS. Literature searches were based on the descriptor "intra-abdominal hypertension", selected from the controlled vocabulary list Descritores em Ciências da Saúde (DeCS) [Health Science Descriptors]; additional, non-controlled descriptors were selected based on terms that came up frequently in the articles studied during the research project formulation phase, as follows: "intra-abdominal pressure", "abdominal compartment syndrome", "acute compartment syndrome", "compartment syndrome of the abdome"; terms in English, Portuguese and Spanish were considered.
Data collection was performed between June and July 2012; titles and abstracts were investigated for selection of articles meeting the following inclusion criteria: articles published in English, Portuguese or Spanish as of 2005; open access publications; articles discussing intravesical IAP monitoring in adults, particularly those focusing on methodological approaches, fluid instillation volumes and measurement frequency. Articles that did not meet the inclusion criteria proposed, or involved animal models, were excluded.

In the fourth phase, selected articles were analyzed and categorized according to five levels of evidence described in the classification from the Oxford Centre for Evidence-Based Medicine 2011 Levels of Evidence. ${ }^{(23)}$

In the fifth phase, variables extracted from articles were summarized, compared and discussed; result presentation charts were prepared, then submitted to descriptive analysis and confronted with literature data. Results were taken into account in the preparation of this article and organized to contribute to the understanding of the core topic of this review.

\section{RESULTS}

Among potential references resulting from database searches, 20 articles met the inclusion criteria proposed in this study.

As regards publication sources, two articles (10\%) were published in Brazilian journals (Revista Brasileira de Clínica Médica and Revista Brasileira de Terapia Intensiva) and 18 (90\%) in the following international journals: Revista Chilena de Cirugía, F1000 Reports Medicine, Critical Care Journal, Cirugía Española, Critical Care Nurse Journal, Scandinavian Journal of Surgery, Journal of Zhejiang Univerty SCIENCE B, British Journal of Anaesthesia, Acta Clinica Belgica, Critical Care Research and Practice, Medicina intensival Sociedad Española de Medicina Intensiva y Unidades Coronarias, Journal of Emergencies Trauma and Shock, Scandinavian Journal of Trauma Resuscitation and Emergency Medicine, and Minerva Anestesiologica.

Most studies were originally from Belgium $(7 ; 35 \%)$, United States $(3 ; 15 \%)$, Brazil $(2 ; 10 \%)$ or Spain $(2$; $10 \%$ ); Canada, China, Greece, Italy, United Kingdom and Chile contributed with $30 \%$ of the articles (one per country). Therefore, $75 \%$ (15) of the studies were published in English, 15\% (3) in Spanish and 10\% (2) in Portuguese. Publication year distribution was almost linear over the period considered.

Study designs were as follows: literature reviews $(60 \% ; 12)$, exploratory-descriptive studies $(20 \% ; 4)$, specialist's opinions $(10 \% ; 2)$, prospective cohort studies $(5 \% ; 1)$ and experience reports. One study had evidence level 3 and 19 articles had evidence level 5. 
Detailed reading permitted further categorization according to article content, as follows: articles discussing intensivists knowledge of IAP, articles focused on ideal saline solution (SS) instillation volume for IAP determination and articles discussing general aspects of intravesical IAP measurement. A summary of articles included in this integrative review is given in charts 1 to 3 .

Chart 1. Summary of articles focusing on intensivists' knowledge of intra-abdominal pressure

\begin{tabular}{|c|c|c|}
\hline Objetives & Features & Results \\
\hline $\begin{array}{l}\text { To investigate IAP and IAH } \\
\text { knowledge, recognition and } \\
\text { management in Italian ICUs }{ }^{(24)}\end{array}$ & $\begin{array}{c}\text { Type: exploratory-descriptive study } \\
\text { Place: Italy } \\
\text { Sample: } 77 \text { physicians in charge of ICUs } \\
\text { Instrument: questionnaire comprising } 9 \text { close-ended questions }\end{array}$ & $\begin{array}{l}\text { IAP was measured in } 51 \text { ICUs. Lack of IAP measurement was } \\
\text { due to lack of a specific kit or unawareness of the technique. The } \\
\text { intravesical method was the only one employed. Frequency of serial } \\
\text { measurements: every } 4 \text { hours in the presence of risk factors }(64.7 \%) \text {, } \\
\text { or in emergency surgical procedures }(21.5 \%)\end{array}$ \\
\hline $\begin{array}{l}\text { To assess knowledge of ACS, clinical } \\
\text { application of IAP measurement, } \\
\text { measurement methods and } \\
\text { frequency, and criteria for } \\
\text { decompressive laparotomy }\end{array}$ & $\begin{array}{l}\text { Type: exploratory-descriptive study } \\
\text { Place: United Kingdom } \\
\text { Sample: } 137 \text { physicians in charge of ICUs } \\
\text { Sample: } 137 \text { physicians in charge of ICUs }\end{array}$ & $\begin{array}{l}\text { IAP was measured by } 104 \text { interviewees in suspected cases of IAH/ } \\
\text { ACS (93.9\%). The intravesical method was the only one employed. } \\
\text { Frequency: } 44.2 \% \text { in the presence of clinical suspicion; } 26.9 \% \text { every } \\
4 \text { to } 8 \text { hours; } 15.4 \% \text { every zero to } 4 \text { hours; } 10.9 \% \text { every } 12 \text { hours; } \\
2.9 \% \text { once every } 24 \text { hours }\end{array}$ \\
\hline $\begin{array}{l}\text { To assess physician's knowledge of } \\
\text { ACS and respective management } \\
\text { characteristics }^{(15)}\end{array}$ & $\begin{array}{c}\text { Type: exploratory-descriptive study } \\
\text { Place: Brazil } \\
\text { Sample: } 90 \text { physicians working at } 10 \text { ICUs in } \\
\text { Rio de Janeiro }\end{array}$ & $\begin{array}{l}\text { IAP was measured in patients clinically predisposed to ACS }(51.4 \%) \\
\text { using the intravesical method }(97 \%) \text {, with instillation of } 60-100 \mathrm{~mL} \text { of } \\
\text { fluid }(54.3 \%) \text {, at 4-to-8-hour intervals }(60 \%) \text {. Methodological issues } \\
\text { were among the major doubts reported in questionnaires }\end{array}$ \\
\hline $\begin{array}{l}\text { To determine the current level } \\
\text { of understanding and clinical } \\
\text { management of IAH/ACS among } \\
\text { intensivists working in Chinese } \\
\text { hospitals }^{(16)}\end{array}$ & $\begin{array}{l}\text { Instrument: questionnaire comprising } 12 \text { close-ended questions } \\
\text { Type: exploratory-descriptive study } \\
\text { Place: China } \\
\text { Sample: } 108 \text { physicians } \\
\text { Instrument: questionnaire comprising } 20 \text { close-ended questions }\end{array}$ & $\begin{array}{l}\text { IAP was measured by } 75 \text { physicians in suspected cases of IAH (88\%); } \\
\text { the intravesical method was used (100\%) with patients in the supine } \\
\text { position ( } 97.3 \% \text { ) and using } 50-100 \mathrm{~mL} \text { of fluid ( } 46.7 \%) \text {; the pubic } \\
\text { symphysis was taken as the zero-reference point ( } 68 \%) \text {. Out of } 33 \\
\text { physicians not measuring IAP, } 36.4 \% \text { were not able to interpret results } \\
\text { and } 27.3 \% \text { had never admitted patients suffering from IAH }\end{array}$ \\
\hline
\end{tabular}

IAP: intra-abdominal pressure; IAH: intra-abdominal hypertension; ICU: intensive care unit; ACS: abdominal compartment syndrome.

Chart 2. Summary of articles focusing on ideal saline solution instillation volume for intra-abdominal pressure measurement

\begin{tabular}{|c|c|c|}
\hline Objetives & Features & Results \\
\hline \multirow{4}{*}{$\begin{array}{l}\text { To assess the effect of different } \\
\text { saline instillation volumes } \\
\text { during intravesical pressure } \\
\text { measurement(26) }\end{array}$} & Type: prospective cohort study & \multirow{4}{*}{$\begin{array}{l}\text { The intravesical method is the gold standard for indirect measurement. Volumes described ranged from } \\
50 \text { to } 300 \mathrm{~mL} \text {. Authors concluded: }>50 \mathrm{~mL} \text { may overestimate true IAP; } 25 \mathrm{~mL} \text { may be enough; vesical } \\
\text { compliance varies within and between patients; a uniform, standardized, accurate and reproducible } \\
\text { method is required for multicenter studies }\end{array}$} \\
\hline & Place: Belgium & \\
\hline & & \\
\hline & to mechanical ventilation & \\
\hline \multirow{2}{*}{$\begin{array}{l}\text { To describe the significance of saline } \\
\text { infusion volume standardization in } \\
\text { IAP monitoring }\end{array}$} & Type: specialist's opinion & \multirow{2}{*}{$\begin{array}{l}\text { The intravesical method is the standard technique for indirect measurement, but there's little } \\
\text { standardization in literature. The most accurate volume is not clear. Small volumes tend to be } \\
\text { employed, as discussed in the studies by Malbrain et al. }{ }^{(26)}(25 \mathrm{~mL}) \text { and Waele et al. }{ }^{(9)}(10 \mathrm{~mL}) \text {, given } \\
\text { IAP overestimation is directly proportional to larger volumes. }\end{array}$} \\
\hline & Place: Canada & \\
\hline
\end{tabular}

IAP: intra-abdominal pressure.

Chart 3. Summary of articles discussing general aspects of intravesical intra-abdominal pressure (IAP) measurement

\begin{tabular}{|c|c|c|}
\hline Objectives & Features & Results \\
\hline $\begin{array}{l}\text { To provide clinical update for accurate } \\
\text { ACS diagnosis and for adequate } \\
\text { management and intervention, with } \\
\text { particular emphasis on intensive care }{ }^{(5)}\end{array}$ & $\begin{array}{c}\text { Type: literature review } \\
\text { Place: Brazil }\end{array}$ & $\begin{array}{l}\text { Simple, low cost; measurements in mmHg, at end-expiration, supine position, absence of abdominal } \\
\text { contractions. Instillation of } 25 \mathrm{~mL} \text {, transducer zeroed at mid-axillary line level and connected to 3-way } \\
\text { stopcock inserted between vesical catheter and drainage bag. Measured in the presence of two or } \\
\text { more risk factors every 4-6 hours; every hour in severe organ dysfunction. Discontinued in absence of } \\
\text { acute organ dysfunction or if IAP }<10 \mathrm{mmHg} \text { for } 24-48 \text { hours }\end{array}$ \\
\hline $\begin{array}{l}\text { To provide updated information, } \\
\text { discuss organ dysfunction } \\
\text { mechanisms, technique, therapeutic } \\
\text { recommendations and treatment }{ }^{(7)}\end{array}$ & $\begin{array}{c}\text { Type: literature review } \\
\text { Place: Belgium }\end{array}$ & $\begin{array}{l}\text { Reference standard for intermittent measurement. Volume: } 20-25 \mathrm{~mL} \text {. Expressed in mmHg, measured } \\
\text { at end-expiration, in complete supine position, in the absence of abdominal muscle contractions, } \\
\text { with transducer zeroed at mid-axillary line level. Recent studies investigated effects of different zero- } \\
\text { reference points and elevated head position }\end{array}$ \\
\hline
\end{tabular}


.... Continuation

Chart 3. Summary of articles discussing general aspects of intravesical intra-abdominal pressure (IAP) measurement

\begin{tabular}{|c|c|c|}
\hline Objectives & Features & Results \\
\hline $\begin{array}{l}\text { To give a broad overview of IAH/ACS, } \\
\text { the role of nurses in assessment, } \\
\text { monitoring and collaborative } \\
\text { management }{ }^{(8)}\end{array}$ & $\begin{array}{l}\text { Type: literature review. } \\
\text { Place: United States }\end{array}$ & $\begin{array}{l}\text { Physical examination not sensitive for IAH detection. Intravesical method is the gold standard for indirect } \\
\text { measurement, despite variations; technique adopted is: } 20-25 \mathrm{~mL} \text { instillation volume, supine position, } \\
\text { zero-reference point at pubic symphysis level, every } 4-6 \text { hours in patients at risk, until underlying cause } \\
\text { resolution is obtained and IAP } \leq 12 \mathrm{mmHg} \text { for } 24-48 \text { hours }\end{array}$ \\
\hline $\begin{array}{l}\text { To serve as reference for } \\
\text { recommendations defined at the III } \\
\text { World ACS Conference }{ }^{(9)}\end{array}$ & $\begin{array}{l}\text { Type: experience report } \\
\text { Place: Belgium }\end{array}$ & $\begin{array}{l}\text { Twelve consensus definitions. About the technique: reference standard for intermittent measurement; } \\
\text { in } \mathrm{mmHg} \text {, at end-expiration, in complete supine position, in the absence of abdominal muscle } \\
\text { contractions, transducer zeroed on the mid-axillary line, at iliac crest level, } 25 \mathrm{~mL} \text { maximum saline } \\
\text { solution instillation volume }\end{array}$ \\
\hline $\begin{array}{l}\text { To describe diagnostic criteria, risk } \\
\text { populations, monitoring techniques } \\
\text { and IAH/ACS management }{ }^{(10)}\end{array}$ & $\begin{array}{l}\text { Type: literature review } \\
\text { Place: United States }\end{array}$ & $\begin{array}{l}\text { Gold standard due to reliability, simplicity and low invasiveness. Measured at end-expiration, zeroed } \\
\text { at phlebostatic axis level, instillation of } 25-50 \mathrm{~mL} \text {. Transient increase in sedation suggested to reduce } \\
\text { interferences. Potential routine protocol: every } 2 \text { hours for the first } 8 \text { hours following ICU admission; } \\
\text { every } 4 \text { hours over the next } 8 \text { hours; and every } 8 \text { hours over the following } 24 \text { hours }\end{array}$ \\
\hline $\begin{array}{l}\text { To review risk factors for IAH/ACS, } \\
\text { related conditions, pathophysiology, } \\
\text { diagnostic methods and therapeutic } \\
\text { advancements }{ }^{(11)}\end{array}$ & $\begin{array}{c}\text { Type: literature review } \\
\text { Place: Spain }\end{array}$ & $\begin{array}{l}\text { Physical examination and diagnosis have low sensitivity for IAH detection. Intravesical method simple, } \\
\text { reliable, reproducible, minimally invasive, low cost, measured at end-expiration, in supine position, zero- } \\
\text { reference point on the mid-axillary line at iliac crest level, in the absence of abdominal contractions, } \\
\text { instillation of } 25 \mathrm{~mL} \text { saline solution }\end{array}$ \\
\hline $\begin{array}{l}\text { To provide a general overview and } \\
\text { present historical aspects, definitions, } \\
\text { pathophysiology and suggestions for } \\
\text { IAH/ACS management }{ }^{(12)}\end{array}$ & $\begin{array}{l}\text { Type: literature review } \\
\text { Place: Greece }\end{array}$ & $\begin{array}{l}\text { Physical examination and imaging modalities not sensitive for IAH detection. Safe, efficient monitoring: } \\
\geq 2 \text { risk factors, one baseline measurement; if IAH, serial measurements. Intravesical method is simple, } \\
\text { low cost, thought to be the gold standard. Measurements taken with patient in supine position }\end{array}$ \\
\hline $\begin{array}{l}\text { To present currently accepted } \\
\text { consensus definitions regarding IAH } \\
\text { and ACS diagnosis and treatment }{ }^{13)}\end{array}$ & $\begin{array}{l}\text { Type: literature review } \\
\text { Place: Belgium }\end{array}$ & $\begin{array}{l}\text { Clinical assessment has low sensitivity in detection of increased IAP. Intravesical method more } \\
\text { widely employed due to simplicity, low cost and minimal risk. Expressed in } \mathrm{mmHg}\left(=1.36 \mathrm{cmH}_{2} 0\right) \text {, } \\
\text { at end-expiration, in complete supine position, in the absence of abdominal muscle contractions, } \\
\text { zero-reference point at mid-axillary line level, instillation volume } \leq 25 \mathrm{~mL}\end{array}$ \\
\hline $\begin{array}{l}\text { To discuss etiology, epidemiological } \\
\text { data, measurement techniques, } \\
\text { diagnosis, complications, prevention } \\
\text { and treatment(14) }\end{array}$ & $\begin{array}{l}\text { Type: literature review } \\
\text { Place: Belgium }\end{array}$ & $\begin{array}{l}\text { Worldwide acceptance due to simplicity and minimal cost, but technique varies. Measured in mmHg, } \\
\text { at end-expiration, in complete supine position, in the absence of abdominal contractions, with } \\
\text { transducer zeroed at mid-axillary line level and maximal saline solution instillation volume of } 25 \mathrm{~mL}\end{array}$ \\
\hline Not mentioned ${ }^{(17)}$ & $\begin{array}{l}\text { Type: literature review } \\
\text { Place: United States }\end{array}$ & $\begin{array}{c}\text { Clinical assessment inaccurate for IAH detection. Measure: upon admission of critically-ill patient, in } \\
\text { the presence of risk factors or clinical deterioration. Other hollow organs were described, but none } \\
\text { as simple and user-friendly as the bladder. Patient in supine position, pressure module zeroed on } \\
\text { the mid-axillary line at iliac crest level }\end{array}$ \\
\hline $\begin{array}{l}\text { To discuss etiology, epidemiological } \\
\text { data, IAP measurement, diagnosis, } \\
\text { complications, prevention and } \\
\text { treatment options for ACS }\end{array}$ & $\begin{array}{l}\text { Type: literature review } \\
\text { Place: Belgium }\end{array}$ & $\begin{array}{l}\text { Physical examination and imaging modalities inaccurate for diagnosis but indicate causes. IAP measured } \\
\text { at one site is assumed to reflect IAP as a whole. Intravesical method is the gold standard due to simplicity } \\
\text { and minimal cost. Several tools have been developed, such as Foley Manometer or AbViser stopcock. } \\
\text { Continuous technique has been described, but is not widely used }\end{array}$ \\
\hline Not mentioned ${ }^{(19)}$ & $\begin{array}{c}\text { Type: literature review } \\
\text { Place: Spain }\end{array}$ & $\begin{array}{l}\text { Patients must be in complete supine position and abdominal muscle contraction must be absent; } \\
\text { transducer is zeroed at pubic symphysis or mid-axillary line level. Instillation of } 25 \mathrm{~mL} \text { of sterile saline } \\
\text { solution; values obtained must be expressed in } \mathrm{mmHg}\end{array}$ \\
\hline Not mentioned ${ }^{(20)}$ & $\begin{array}{c}\text { Type: literature review } \\
\text { Place: Chile }\end{array}$ & $\begin{array}{l}\text { Clinical assessment has low sensitivity ( } 40 \% \text { ) for IAH estimation. IAP increasingly employed due to } \\
\text { relevance of early IAH detection and management; transducer zeroed at pubis level. Original technique } \\
\text { employed } 50-100 \mathrm{~mL} \text { but recent study reported better correlation with IAP when } 50 \mathrm{~mL} \text { are used }\end{array}$ \\
\hline Not mentioned ${ }^{(28)}$ & $\begin{array}{l}\text { Type: specialist's opinion } \\
\text { Place: Belgium }\end{array}$ & $\begin{array}{l}\text { Despite increased attention given to topic, general clinical application has not been established to date. } \\
\text { Current consensus on ideal measurement method or time point is lacking. Future research efforts should } \\
\text { aim to improve consensus definitions concerning IAH and ACS }\end{array}$ \\
\hline
\end{tabular}

ACS: abdominal compartment syndrome; IAH: intra-abdominal hypertension; IAP: intra-abdominal pressure; ICU: intensive care unit.

\section{DISCUSSION}

Organ perfusion compromise may develop whenever intracompartmental pressure exceeds capillary blood pressure. Deleterious consequences of IAP have been described more than 150 years ago; still only over the two last decades have IAP-related concerns been rediscovered and better characterized, with recently acquired clinical significance. ${ }^{(5,13,15,25)}$
Historically, several authors have tried to come up with an ideal IAP measurement method. Using a tube connected to a manometer, Schatz was able to measure intrauterine pressure in 1872. One year later, Wendt measured IPA through the rectum and, in 1875, Odebrecht did the same in the urinary bladder. ${ }^{(12)}$ The IAH concept developed by these researchers was put aside after the World War I and rediscovered by the end 
of the $20^{\text {th }}$ century, through the pioneer work of Kron, Harman and Nolan (1984), ${ }^{(5,8,12,13)}$ describing the original IAP measurement method. Bearing in mind the ability of the urinary bladder to act as a passive container at volumes of 50 to $100 \mathrm{ml}$, these authors hypothesized IAP could be accurately measured via an indwelling urinary catheter (IUC). ${ }^{(29)}$

Increased IAP is common in critically ill patients and is thought to be an independent mortality

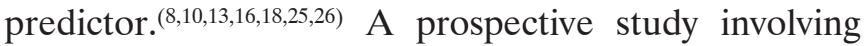
13 intensive care unit (ICUs) in Belgium, Austria, Israel, Brazil and Australia reported IAH and ACS prevalence of $32.1 \%$ and $4.2 \%$, respectively, upon patient admission. ${ }^{(5,16)}$ A second study revealed significantly higher mortality indices in critically ill patients presenting with increased IAP compared to unaffected patients (37.9\% and $19.1 \%$ respectively). ${ }^{(8,16)}$ These data suggest increased IAP is common among critically ill patients, and may increase morbidity and mortality risks.

However, IAP measurement is not recommended for all ICU patients. The major indications comprise patients presenting with two or more risk factors, patient screening upon ICU admission or presence of progressive or new organ failure. ${ }^{(5,12,16)}$ In such cases, IAP should be monitored at 4-to-6-hour intervals, with hourly IAP monitoring restricted to patients suffering from severe organ dysfunction. ${ }^{(5,8,12,17)}$ In actual fact, in many cases IAP measurement is restricted to suspected cases of IAH; ${ }^{(15)}$ hence, implementation of routine IAP monitoring is paramount for IAH/ACS recognition and effective treatment. ${ }^{(10,13)}$

Massive fluid replacement, polytransfusion, open abdomen management, hypothermia, coagulopathy, systemic inflammatory response syndrome, severe sepsis or septic shock, hepatic dysfunction with ascites, mechanical ventilation and positive-end expiratory pressures (PEEP) above $10 \mathrm{cmH}_{2} \mathrm{O}$ are the major risk factors for IAH and ACS. ${ }^{(5,10)}$

Although IAH and ACS are not synonymous, both conditions reflect different stages of the same pathological process $^{(5)}$ and affect all organ systems, with more evident manifestations in ACS. ${ }^{(16,26,27)}$ Clinical presentation generally includes a tense, distended abdomen, hypotension, high airway pressure, hypercapnia and oliguria. ${ }^{(25)}$

Clinical examination is thought to be a poor, low sensitivity (40 to $60 \%$ ) IAP estimation tool. ${ }^{(8,11-13,17,18,20,27)}$ Abdominal circumference is another low sensitivity IAP estimation method, as are available imaging techniques, which basically provide etiological data and help support decision making. ${ }^{(8,11-13,17,18,20,27)}$ Therefore, multidisciplinary team members must be aware of proper IAP measurement techniques for correct diagnosis and management of IAH patients. $^{(8,12,26)}$ Inaccurate IAP measurements or failure to convert values given in $\mathrm{cmH}_{2} \mathrm{O}$ into $\mathrm{mmHg}$ may translate into incorrect indications for surgical abdominal decompression, with increased complication risks for patients. Also, erroneous recognition of IAH as the cause of the patient's condition may lead to changes in support treatment and ventilation parameters, or mislead physicians into ruling out other diagnostic possibilities. ${ }^{(27)}$

Early recognition and proper staging of risk patients are vital for effective treatment. The management is based on four principles: (1) serial IAP monitoring; (2) systemic organ perfusion optimization; (3) introduction of specific procedures aimed at IAP control and mitigation of potential consequences for target organs; and (4) fast surgical decompression in refractory ACS cases. Three algorithms (assessment, management and medical management) can be found at the World Society of the Abdominal Compartment Syndrome (WSACS) website at www.wsacs.org. ${ }^{(16,27)}$

Despite the growing number of publications over the last few years, IAP measurement techniques and clinical applicability have not been fully established to date. ${ }^{(15,16,25,28)}$ As clearly demonstrated in studies involving intensivists (Chart 1). Intravesical IAP measurement is a consensus; however, zero-reference point, infusion volume, measurement frequency and indications remain debatable. . $^{(15,16,24,25)}$

Lack of consensus definitions and the confusion arising from constraints related to interstudy comparisons fostered the creation of the WSACS, a non-for-profit society founded by a multinational group of physicians, in 2004, with the purpose of promoting research and education, as well as improving survival of IAH/ACS patients.

The first WSACS conference, held in 2004, represented a milestone with respect to normalization of definitions, diagnostic criteria, treatment modalities and recommendations concerning future research topics, always based on robust evidences, recommendations and the 12 consensus definitions. As to IAP measurement techniques, definitions 4 and 5 should be emphasized. One definition states that IAP should be expressed in $\mathrm{mmHg}\left(1 \mathrm{mmHg}\right.$ equals $\left.1.36 \mathrm{cmH}_{2} \mathrm{O}\right)$ and measurements performed at end-expiration, with the patient in complete supine position and in the absence of abdominal muscle contractions; the transducer should be zeroed on the mid-axillary line, at the level of the iliac crest. According to another definition, the reference standard for intermittent IAP measurement is via the bladder, with a maximal infusion volume of $25 \mathrm{~mL}$ of sterile saline. ${ }^{(13,16,18,19)}$ 
The WSACS lists laparoscopic and intravesical IAP measurement as the direct and indirect measurement methods of choice respectively. ${ }^{(5,8,10,18,26,27)}$ However, regardless of wide intravesical IAP measurement acceptance, instillation volumes have not been standardized and may range from 50 to $300 \mathrm{ml} .^{(10,18,26)}$ In one study testing different instillation volumes (Chart 2), high volumes were associated with high IAP values; overestimation was thought to result from increased intrinsic pressure, in contrast with data given by Kron et al. ${ }^{(29)}$ Pressure elevation was already relevant at the $25 \mathrm{~mL}$ level, but acquired statistical significance from $75 \mathrm{~mL}$ in most patients. Given the lack of robust data, the authors of that study suggested maximal instillation volumes of $25 \mathrm{~mL}$ would be enough to create a fluid column and remove air. These results were supported by De Waele et al. ${ }^{(9)}$ who considered $10 \mathrm{~mL}$ to be enough for IAP estimation. The same study also pointed out that fluid temperature, as well as infusion speed and volume, may lead to contraction of the detrusor muscle of the bladder; slower infusion of warm (body temperature) fluid is therefore recommended, with measurements taken 30 to 60 seconds after Instillation. ${ }^{(26,27)}$

Intravesical IAP measurement is currently the most widely accepted technique given its simplicity, ${ }^{(5,10-14,17,18)}$ reliability, ${ }^{(10,11)}$ user-friendliness ${ }^{(1,7)}$ and reproducibility, ${ }^{(11,13)}$ with the added benefits of low cost, ${ }^{(5,11-14,18,20)}$ little invasiveness $^{(10,11)}$ and minimal complication risks. ${ }^{(13)}$

The original description given by Kron et al. is as follows: using an IUC and with the closed-system urine drainage bag tubing clamped, the bladder is instilled with 50 to $100 \mathrm{~mL}$ of saline solution; a pressure transducer or water column is then connected via a 16-gauge needle inserted through the aspiration port located at the proximal portion of the extensor tube for IAP estimation. The transducer should be zeroed at and the fluid column leveled with the pubic symphysis, with the patient in the dorsal position. ${ }^{(29)}$

Variations of the original technique have been described. Currently, tools for IAP measurement are readily available in hospital units and specialized WSACS approved kits can be purchased; kit selection should be based on features such as reproducibility, team safety, efficacy and cost. ${ }^{(8,18)}$

Intra-abdominal pressure measurement using pressure transducers is shown in figure 1 . The assembled system is filled with saline solution and connected to the aspiration port. With the transducer positioned at point zero, the drainage bag tube clamp is closed; aspiration and instillation of $25 \mathrm{~mL}$ of saline follows and readings are then performed. The drainage bag tube clamp must be released at the end of the procedure. ${ }^{(8)}$
Intra-abdominal pressure measurement using a pressure transducer connected to a stopcock system is shown in figure 2 . With the system set up and filled with SS, and the transducer positioned at point zero, the first stopcock is turned off to the patient and on to the fluid bag; the stopcock to the syringe is open and saline solution $(25 \mathrm{~mL})$ is aspirated. The first stopcock is turned off to the fluid bag and, leaving the second

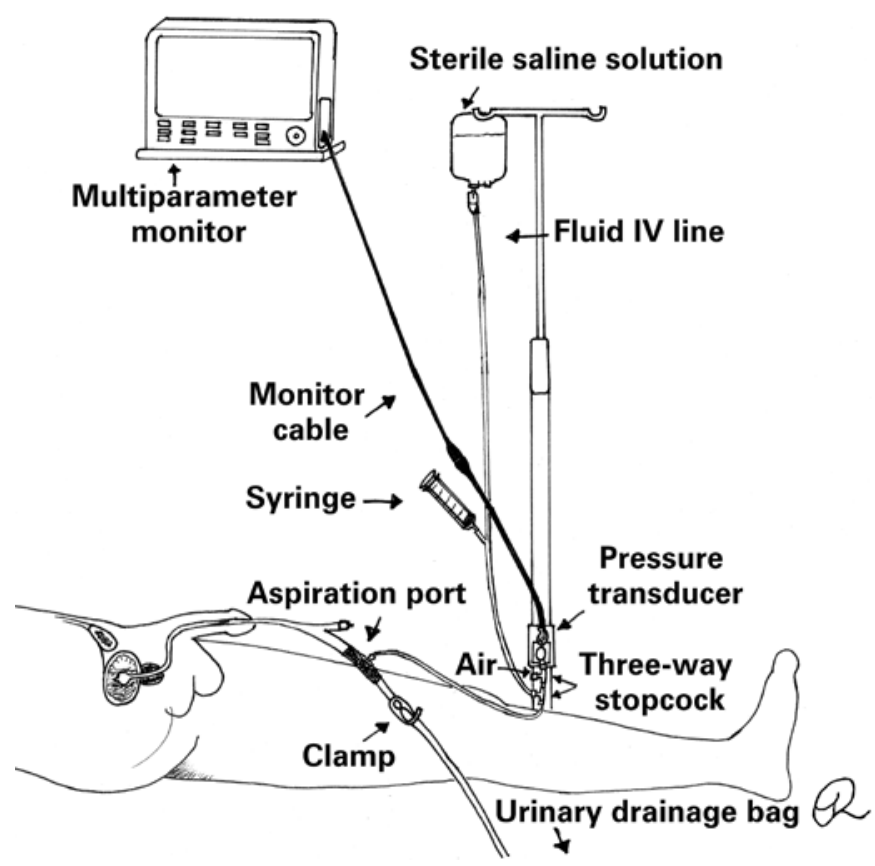

Figure 1. Intra-abdominal pressure measurement using the pressure transducer technique

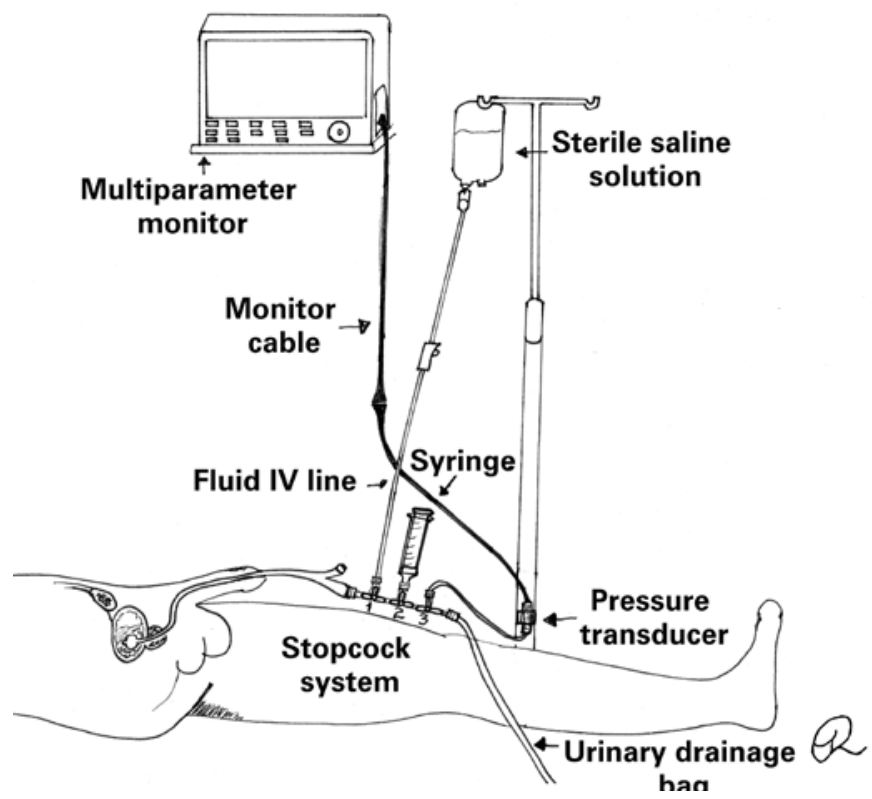

Figure 2. Intra-abdominal pressure measurement using the pressure transducer technique and a three-way stopcock system 
stopcock open (from the syringe to the IUC), SS is instilled. The second stopcock is the turned off to the syringe and the third stopcock adjusted so as to interrupt the flow towards the drainage bag. After ensuring the third stopcock is turned off to the transducer, the flow towards the drainage bag is released. ${ }^{(8)}$

Intra-abdominal pressure measurement using the U-tube technique figure 3 lacks robust clinical validation and is recommended for tracking only. A ruler (in centimeters) is placed vertically at point zero; the urinary catheter is then raised and the proximal aspect of the urinary drainage bag leveled with the starting point of the ruler; finally, measurements are taken using the fluid column that is formed. ${ }^{(8)}$

A fourth IAP measurement technique figure 4 commonly used in Brazilian hospitals, employs a Y-set. With the fork leveled with the zero point of a

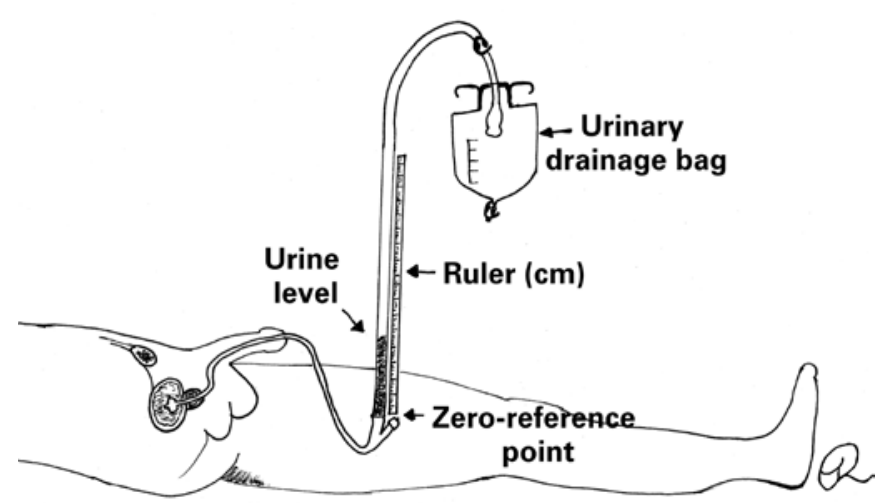

Figure 3. Intra-abdominal pressure measurement using the U-tube technique

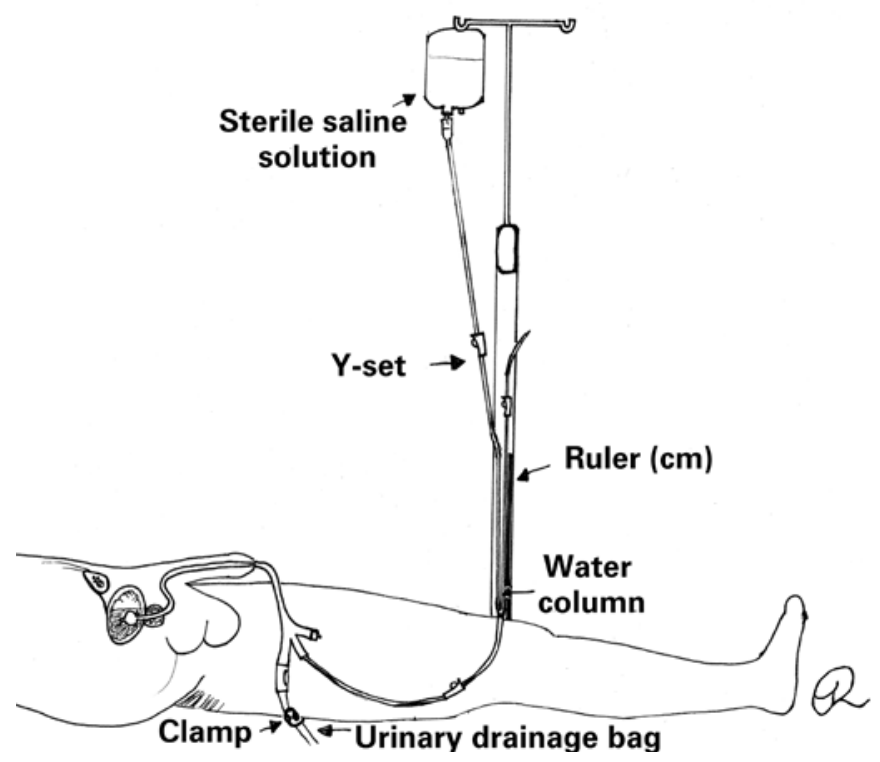

Figure 4. Intra-abdominal pressure measurement using the $\mathrm{Y}$-set technique measuring tape $(\mathrm{cm})$ and a fluid bag SS connected to one end, both ends are laid over the ruler. The system is then filled with saline and connected to the third IUC stopcock prior to drainage bag tube clamping and infusion of $25 \mathrm{~mL}$ of SS. Within 30 to 60 seconds the measuring system is opened to the catheter and water column and pressure readings in $\mathrm{cmH}_{2} \mathrm{O}$ taken and converted into $\mathrm{mmHg}$. The measuring system is closed and the urinary drainage bag clamp released at the end of the procedure. ${ }^{(1,2)}$

A continuous measuring technique has been described, but standardization level is low and application and benefits are disputable..$^{(8,27)}$

\section{CONCLUSION}

This study clarified some aspects of intra-abdominal pressure measurement. Methodological variations recognized by the World Society of the Abdominal Compartment Syndrome have been highlighted. Inaccuracy of clinical assessment and imaging modalities in intraabdominal pressure determination was shown to be a consensus, with intravesical intra-abdominal pressure measurement being the method of choice due to simplicity and low cost.

Technical aspects found support in consensus definitions: Intra-abdominal pressure should be expressed in $\mathrm{mmHg}$ and measured in the supine position, at end-expiration and in the absence of abdominal muscle contraction.

With regards to methodological differences, most articles recommended transducer zeroing on the midaxillary line, at iliac crest level, while three suggested the pubic symphysis as the zero-reference point. Sterile saline instillation volume is variable; however, a maximal volume of $25 \mathrm{~mL}$ is recommended in most studies. Inherent procedural risks were not discussed.

Doubts regarding intra-abdominal pressure measurement in clinical practice persists despite widely available, normalized information. Studies providing robust evidences are lacking.

\section{REFERENCES}

1. Viana RA. Enfermagem em terapia intensiva: práticas baseadas em evidências São Paulo: Atheneu; 2011. p.560.

2. Viana RA, Whitaker IY. Enfermagem em terapia intensiva: práticas e vivências Porto Alegre: Artmed; 2011. p.546.

3. Knobel E. Terapia intensiva: enfermagem. São Paulo: Atheneu; 2006. p. 656.

4. Baird MS, Bethel S. Manual de enfermagem no cuidado crítico: intervenções de enfermagem e condutas colaborativas. 6a ed. Rio de Janeiro: Elsevier; 2012. p. 1016.

5. Bersani AL, Gomes JO, Braga IL, Guimarães HP, Lopes RD. Síndrome compartimental abdominal. Rev Bras Clin Med. 2009;7:313-21. 
6. Jeronimo RA, Cheregatti A. Técnicas de UTI. São Paulo: Rideel; 2010. p. 344.

7. Malbrain M. Abdominal compartment syndrome. F1000 Med Rep. 2009;1. pii: 86.

8. Lee RK. Intra-abdominal hypertension and abdominal compartment syndrome: a comprehensive overview. Crit Care Nurse. 2012;32(1):19-31. Review.

9. De Waele JJ, Cheatham ML, Malbrain ML, Kirkpatrick AW, Sugrue M, Balogh $Z$, et al. Recommendations for research from the international conference of experts on Intra-abdominal Hypertension and Abdominal Compartment Syndrome. Acta Clin Belg. 2009;64(3):203-9.

10. Luckianow GM, Ellis M, Governale D, Kaplan LJ. Abdominal compartment syndrome: risk factors, diagnosis, and current therapy. Crit Care Res Pract. 2012;2012:908169.

11. Sánchez-Miralles A, Castellanos G, Badenes R, Conejero R. [Abdominal compartment syndrome and acute intestinal distress syndrome]. Med Intensiva. 2013;37(2):99-109. Review. Spanish.

12. Papavramidis TS, Marinis AD, Pliakos I, Kesisoglou I, Papavramidou N. Abdominal compartment syndrome - Intra-abdominal hypertension: Defining, diagnosing, and managing. J Emerg Trauma Shock. 2011;4(2):279-91.

13. Cheatham ML. Abdominal compartment syndrome: pathophysiology and definitions. Scand J Trauma Resusc Emerg Med. 2009;17:10. Review.

14. Malbrain ML, Vidts W, Ravyts M, De Laet I, De Waele J. Acute intestinal distress syndrome: the importance of intra-abdominal pressure. Minerva Anestesiol. 2008;74(11):657-73. Review.

15. Japiassú AM, Falcão $H$, Freitas F, Freitas $S$, Souza PC, Lannes $R$, et al. Mensuração da pressão intra-abdominal nas unidades de tratamento intensivo: a opinião dos médicos intensivistas. Rev Bras Ter Intensiva. 2007;19(2):186-91.

16. Zhou JC, Zhao HC, Pan KH, Xu QP. Current recognition and management of intra-abdominal hypertension and abdominal compartment syndrome among tertiary Chinese intensive care physicians. J Zhejiang Univ Sci B. 2011;12(2): 156-62.

17. Ball CG, Kirkpatrick AW. Intra-abdominal hypertension and the abdominal compartment syndrome. Scand J Surg. 2007;96(3):197-204. Review.
18. de Laet IE, Malbrain M. Current insights in intra-abdominal hypertension and abdominal compartment syndrome. Med Intensiva. 2007;31(2):88-99. Review.

19. Castellanos G, Piñero A, Fernández JA. [Intra-abdominal hypertension and abdominal compartment syndrome. What should surgeons know and how should they manage these entities?]. Cir Esp. 2007;81(1):4-11. Review. Spanish.

20. Losada HM, Manterola CD, Vial MG, Pineda VN. Hipertensión abdominal y syndrome de compartimiento abdominal. Rev Chilena Cirugía. 2005;57(1):2-6.

21. Bisinelli F, Mendes M, Lourenço TM. Monitorização da Pressão Intra-abdominal: conhecimento da equipe de enfermagem. Bol Enferm. 2008;2(2): 1-10.

22. Oliveira VC, Souza AC. Pressão intra-abdominal: parâmetro vital para a assistência de enfermagem ao paciente crítico. Anais 61ํㅡㄹ Congresso de Enfermagem: transformação social e sustentabilidade ambiental [Internet]. Fortaleza; 2009 [cited 2015 Aug 8]. Available at: http://www.abeneventos.com.br/ anais_61cben/files/01595.pdf

23. OCEBM Levels of Evidence Working Group. The Oxford 2011 Levels of Evidence. Oxford Centre for Evidence-Based Medicine [Internet]. 2011 [cited 2015 Aug 8]. Available at: www.cebm.net/mod_product/design/files/ CEBM-Levels-of-Evidence-2.1.pdf

24. Biancofiore G, Bindi ML. Measurement and knowledge of intra-abdominal pressure in Italian Intensive Care Units. Minerva Anestesiol. 2008;74(1-2): 5-8;quiz 9.

25. Ravishankar $\mathrm{N}$, Hunter J. Measurement of intra-abdominal pressure in intensive care units in the United Kingdom: a national postal questionnaire study. $\mathrm{Br} J$ Anaesth. 2005;94(6):763-6.

26. Malbrain ML, Deeren DH. Effect of bladder volume on measured intravesical pressure: a prospective cohort study. Crit Care. 2006;10(4):R98.

27. Ball CG, Kirkpatrick AW. Progression towards the minimum: the importance of standardizing the priming volume during the indirect measurement of intra-abdominal pressures. Crit Care. 2006;10(4):153. Review.

28. Malbrain ML. You don't have any excuse, just start measuring abdominal pressure and act upon it! Minerva Anestesiol. 2008;74(1-2):1-2.

29. Kron IL, Harman PK, Nolan SP. The measurement of intra-abdominal pressure as a criterion for abdominal re-exploration. Ann Surg. 1984;199(1):28-30. 